\title{
ХІРУРГІЯ
}

\section{АНАЛІЗ МІСЦЕВИХ ТА ЗАГАЛЬНИХ УСКЛАДНЕНЬ ПРИ ЛІКУВАННІ ПЕРВИННИХ ТА ПІСЛЯОПЕРАЦІЙНИХ ВЕНТРАЛЬНИХ ГРИЖ ЗА ПЕРІОД 2001-2017 РР.}

\begin{abstract}
Резюме. Упровадження в хірургічну практику сучасних методів та алопластичних матеріалів значно покращило результати хірургічного лікування хворих на вентральну та післяопераційну вентральну грижу. Проте імплантація синтетичного матеріалу в тканини передньої черевної стінки не позбавлена недоліків при їх застосуванні, так як супроводжується різною місцевою реакцією тканин, особливо при імплантації "важких" сіток, що призводить до розвитку ускладнень, частота яких становить від 7,9 до 49,2 \%. Аналіз отриманих результатів зумовлює актуальність даного дослідження.

Мета дослідження - проаналізувати та оцінити основні причини виникнення місцевих та загальних ускладнень при лікуванні хворих на первинні та післяопераційні вентральні грижі.

Матеріали і методи. Сформовано два періоди дослідження із числа 1419 оперованих: з 2001 р. до 2009 р. 597 (42,07 \%) пацієнтів - група порівняння та з 2010 р. до 2017 р. 822 (57,93 \%) особи - основна група. У групі порівняння осіб із первинною вентральною грижею було 286 (47,91 \%), а в основній групі з первинними грижами - 344 (41,85 \%); $з$ післяопераційними в групі порівняння - 311 (52,09 \%) осіб, а в основній - 478 (58,15\%).

Результати досліджень та їх обговорення. 3 усіх 1419 оперованих пацієнтів місцеві ранні післяопераційні ускладнення діагностовано у 522 (36,78 \%) осіб. Загальні ранні ускладнення ми встановили у 76 (5,36 \%) пацієнтів. У групі порівняння місцеві ускладнення мали місце у 311 (52,09 \%) хворих, а в основній групі - у 211 (25,67 \%) осіб. Така ж тенденція була при розподілі загальних ускладнень: 53 (8,88 \%) та 23 (2,79 \%) відповідно. Серому ми спостерігали у 124 (23,75\%), інфільтрати - у $156(28,88 \%)$, гематому - в 102 (19,54\%), нагноєння - у 34 (6,51 \%), тривалу лімфорею - в 65 (12,45\%) пацієнтів. Загальні ускладнення серед 1419 хворих обох груп діагностовано у 76 (5,35 \%) осіб. У групі порівняння їх було $53(8,87$ \%) випадків, в основній групі - 23 (2,79 \%). Серед пізніх місцевих ускладнень найчастіше спостерігали лігатурні нориці, особливо в період 2001-2009 рр. - 27 (4,52 \%). В основній групі дане ускладнення виявлено лише у 3 (0,36 \%) пацієнтів. Відторгнення поліпропіленової сітки (ППС) було у 15 (2,51 \%) випадків. Під час клінічного дослідження мешома виникла в 10 (1,67 \%) осіб групи порівняння та у 7 (0,85\%) - основної групи, міграцію сітки виявили у 9 (1,0\%) та 5 (0,61 \%) осіб групи порівняння та основної групи. У $250(17,62 \%)$ пацієнтів після різних типів операційних втручань розвинувся рецидив грижі.

Висновки. Впровадження сучасних та удосконалення існуючих способів хірургічного лікування хворих на первинні та післяопераційні вентральні грижі зменшило кількість ранніх місцевих та загальних, а також пізніх ускладнень майже в 2 рази.
\end{abstract}

Ключові слова: вентральна грижа; післяопераційна вентральна грижа; алогерніопластика; ускладнення.

ВСТУП На сьогодні висока частота ускладнень і рецидивів первинної вентральної грижі (ПВГ) і післяопераційної вентральної грижі (ПОВГ) пов'язана із достатньо широким застосуванням аутопластичних методів закриття десектів передньої черевної стінки, що супроводжуються надмірним натягом тканин, які здебільшого є дегенеративно зміненими, що призводить до неспроможності швів, утворення сером, гематом, а при інфрікуванні - до нагноєння ран [7, 12-15]. Широке впровадження і використання алопластичних матеріалів у лікуванні ПВГ і ПОВГ істотно змінило підходи та саму техніку виконання операційних втручань $[1,10]$. Без сумніву, алогерніопластика зменшує ймовірність рецидиву грижі за рахунок закриття грижового десекту без натягу тканин. 3 огляду на це, більшість хірургів все частіше надає перевагу застосуванню сучасних полімерних матеріалів для алопластичного закриття грижових воріт при лікуванні пацієнтів із ПВГ і ПОВГ, що сприяє зниженню загальної частоти ускладнень та рецидивів [11]. Проте імплантація синтетичного матеріалу в тканини передньої черевної стінки не позбавлена недоліків при їх застосуванні, так як супроводжується різною місцевою реакцією тканин, особливо при імплантації різних типів поліпропіленових сіток (ППС), які вирізняються різною питомою вагою вмісту пролену. Так "важка" поліпропіленова сітка, як більший подразник, провокує подовжену фразу асептичного запалення з вираженою ексудацією, що у пацієнтів із цукровим діабетом та низькою імунорезистентністю призводить до розвитку ранових ускладнень, частота яких становить від 7,9 до 49,2 \% і як наслідок рецидиву [8, 10, 11]. Недосконала техніка виконання алогерніопластики, вибір неадекватного способу виконання операційного втручання та типу сітчастого протеза, тривалість операційного втручання часто без урахування коморбідної патології у пацієнтів призводить до виникнення післяопераційних ускладнень та рецидивувань $[1,6,9]$.

Синдром недиференційованої дисплазії сполучної тканини ще один стан, який за останні 15-20 років все частіше фрігурує в якості патогенетичного предиктора розвитку як первинних, так і ПОВГ. Особливо це актуально при виконанні операційних втручань у пацієнтів із рецидивом, так як у більшості випадків хірурги не враховують і не беруть до уваги наявність цього синдрому. Численні заходи профрілактики ранових ускладнень, які розроблено на даний час, не дають змоги цілком їх уникнути [3-5].

Метою дослідження було проаналізувати та оцінити причини виникнення місцевих та загальних ускладнень при лікуванні хворих на первинні та післяопераційні вентральні грижі.

МАТЕРІАЛИ І МЕТОДИ Згідно з метою дослідження, на базі хірургії Навчально-наукового інституту післядипломної освіти ДВНЗ "Тернопільський державний медичний університет імені І. Я. Горбачевського МОЗ України" 
(хірургічне відділення КНП “Тернопільська комунальна міська лікарня № 2") проведено поглиблений аналіз місцевих та загальних ускладнень після хірургічного лікуванні первинних та післяопераційних вентральних гриж за період 2001-2017 рр.

Прооперували 1419 пацієнтів, яких поділили на групи відповідно до періодів хірургічного лікування. Для цієї мети сорормовано два періоди: з 2001 р. до 2009 р. та з 2010 р. до 2017 р. У першому періоді обстежено та прооперовано 597 (42,07 \%) хворих. Ці пацієнти склали групу порівняння. Основну групу склали 822 (57,93 \%) осіб, які пролікували в період з 2010 р. до 2017 р. В групі порівняння осіб з первинною вентральною грижею було 286 (47,91 \%), а з післяопераційними - 311 (52,09 \%) осіб. В основній групі 3 первинними грижами - 344 (41,85 \%) та з післяопераційними - 478 (58,15 \%) відповідно. Серед первинних вентральних гриж дефекти М1 у групі порівняння та основній групі виявлено у 7 (2,45 \%) та 15 (4,36 \%) відповідно; M1-3 - 186 (65,03 \%) та 225 (65,41 \%) відповідно; М3 - 86 (30,07 \%) та 73 (21,22 \%) відповідно. Десектів M4-5 в обох групах серед первинних гриж не було. Десректи L4 спостерігали у 7 (2,45 \%) та 31 (9,01 \%) оперованих обох груп. Дефектів інших локалізацій (L1-L3) не було.

У пацієнтів із післяопераційною вентральною грижею в групі порівняння локалізація M1-3 - 232 (74,60 \%), M4-551 (16,40\%). Варіантів М1-5 в цій групі не було виявлено. Десректи L1, L2, L4 були в 17 (5,47 \%). Комбіновані десекти $\mathrm{ML}$ - в 11 (3,53 \%) випадках. В основній групі серед післяопераційних вентральних гриж $(\mathrm{n}=478)$ діагностовано наступну локалізацію та поширення дефектів передньої черевної стінки: М1-3 - 297 (62,13\%), M4-5 - 63 (13,18\%), а варіант M1-5 у цій групі - в 47 (9,83 \%) осіб. Десректи L1, L2, L4 були у 23 (4,81 \%). Комбіновані десекти ML у цій групі виявили у 48 (10,05 \%) пацієнтів. Усім хворим виконували такі операційні втручання: герніопластику власнетканинну (ВТГП) - у 438 (30,87\%), за типами "onlay" - у 463 (32,63\%), "inlay" - 107 (7,54\%), "sublay" - 366 (25,79\%) та сепараційну "CST" - у 45 (3,19\%).

РЕЗУЛЬТАТИ ДОСЛІДЖЕНЬ ТА ЇХ ОБГОВОРЕННЯ Типово після усіх операційних втручань виділяють ранні та пізні ускладнення як загального, так і локального характеру. Враховуючи специфріку операційних втручань з приводу ПВГ та ПОВГ, ми виявляли такі ранні ускладнення. 3 усіх 1419 оперованих пацієнтів місцеві ранні післяопераційні ускладнення діагностовано у 522 (36,78 \%) осіб. Загальні ранні ускладнення ми встановили у 76 (5,36 \%) пацієнтів. У групі порівняння місцеві ускладнення мали місце у 311 (52,09\%) хворих, а в основній групі - в 211 $(25,67 \%)$ осіб. Така ж тенденція була при розподілі загальних ускладнень: 53 (8,88 \%) та 23 (2,79\%) відповідно.

Серед пізніх ускладнень у групі порівняння було виявлено 221 (37,02 \%) та 115 (13,99 \%) випадків відповідно. Це пояснюється удосконаленням хірургічної техніки, упровадженням новітніх способів виконання операційного втручання, диференційованим підходом до використання різних типів сітчастих імплантів та сучасного шовного матеріалу. Також розроблено адекватні способи гемостазу, профрілактики ранового інфрікування, способи дренування післяопераційних ран та широке впровадження в клінічну практику сонографрічного методу моніторингу в ранньому післяопераційному періоді.

Що стосується пізніх ускладнень, то спостерігається чітке зменшення їх кількості за період з 2010 р. майже в 3 рази, порівняно з 2001-2009 рр., що знову ж таки зу- мовлено тактико-технічними удосконаленнями та сучасним імплантаційними матеріалами.

Серому ми спостерігали у 85 (14,28 \%) осіб із ПВГ та ПОВГ групи порівняння, переважно після виконання методик "onlay" - 73 (85,88 \%) та "inlay" - 12 (14,12 \%). Клінічно вона характеризувалася відмежованим скупченням рідини над та під сіткою в підшкірно-жировій клітковині, що містилися або ізольовано, або з'єднувалися між собою (рис. 1). Це пояснюється значним відсепаруванням підшкірно-жирового клаптя від апоневрозу для широкої фріксації ППС, без додаткової фріксації його до апоневрозу, з утворенням "мертвих просторів", великими ділянками термічного опіку, створеного електрокоагуляцією та неадекватним дренуванням.

Дане ускладнення виявляли переважно клінічно. На 6-12 доби післяопераційного періоду після видалення активного дренажу 3 підшкірно-жировою клітковиною (ПЖК) виникала локальна болючість, у деяких випадках серому вдавалося про пальпувати, спостерігали підвищення температури до $38^{\circ} \mathrm{C}$, загальну слабість, що підтверджували під час контрольного УЗД передньої черевної стінки.

Лікували такі рідинні скупчення здебільшого пункційним методом під контролем УЗД з обов'язковим посівом їх вмісту на мікрофрлору та призначали нестероїдні протизапальні препарати. Як правило, на 7-9 доби після пункційного дренування серому ліквідовували.

У літературі, доступній нам, ми не знайшли жодного повідомлення про роль і частоту грибкового ураження у розвитку ранніх післяопераційних ускладнень після алогерніопластик.

Анатомо-топографрічні особливості передньої черевної стінки у пацієнтів із черевними грижами, а саме наявність грижі з надмірним розвитком підшкірної жирової клітковини, фрормують утворення шкірних складок 3 ідеальними умовами для розвитку грибкових інфекцій. До групи фракторів ризику розвитку мікозів пацієнтів із черевними грижами належать: гіповітаміноз, хвороби крові, захворювання печінки, генетична схильність, імуносупресія, зумовлена тривалим застосуванням антибіотиків, цитостатиків і гормональних препаратів, ендокринопатії (цукровий діабет), ожиріння [2].

Тому цікавими були такі випадки, коли в пункційному матеріалі констатували наявність значної кількості гриб-

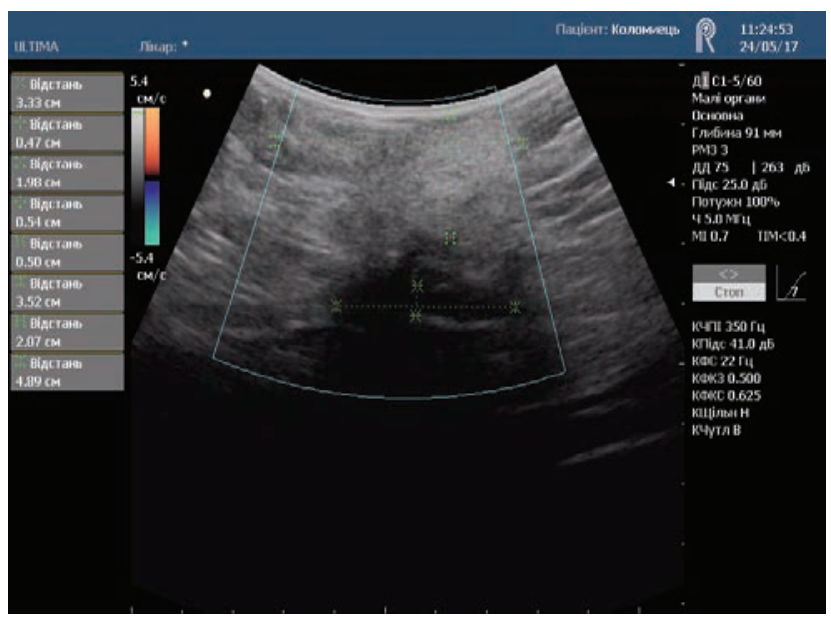

Рис. 1. Серома після алогерніопластики за типом «onlay» за даними сонографії. 
кової фрлори: Aspergillus, Candida, Fusarium, Rhizopus. Тому лікування доповнювали застосуванням системних антимікотичних засобів. Це були хворі переважно з ожирінням II-III ступенів, цукровим діабетом та "висячими" животами.

В основній групі виявляли сероми тільки в 39 (4,74\%) осіб, переважно після виконання методик "onlay" - 22 (56,41 \%), "inlay" - 7 (17,95 \%), а також після роз'єднання анатомічних компонентів передньої черевної стінки в комбінації з сіткою - 10 (25,64 \%). Зменшення частоти виникнення даного ускладнення в цих пацієнтів пояснюється прецизійною технікою сепарації шарів передньої черевної стінки, адекватним гемостазом із використанням біполярної електрокоагуляції в рідинному середовищі (постійне орошення рани охолодженим розчином антисептика) та більш частим використанням "легких" ППС. Тому в пацієнтів даної групи сероми переважно були невеликих розмірів (рис. 2)

Наступним за частотою ускладненням, яке ми виявляли в групі порівняння, були інфрільтрати - у 82 (13,74 \%) пацієнтів. Причинами їх розвитку вважаємо значну травматичність операційних втручань (відсепарування обширних шкірно-жирових клаптів від апоневрозу, дерматоліпектомія, множинні вогнища некрозів після електрокоагуляції), що збільшувало тривалість втручання і, як наслідок, імовірність інфрікування післяопераційної рани. Після виконання методик "onlay" в цій групі інорільтрати виявлено у 23 (28,04 \%), "inlay" - 20 (24,39\%), "sublay" 15 (18,29 \%), ВТГП - 24 (29,27 \%) випадках.

В основній групі дане ускладнення діагностовано у 74 $(9,0 \%)$ осіб. В цій групі найчастіше інфрільтрат виявляли після "CST"-герніопластики - 42 (56,75 \%) хворих. Дана методика $€$ методом вибору при великих та гігантських ПОВГ і супроводжується значною травматизацією тканин передньої черевної стінки.

Після проведення інших типів операційних втручань у даній групі інсрільтрати були: "onlay" - 16 (21,62 \%), "inlay" - 6 (8,11 \%), "sublay" - 7 (9,46\%), ВТГП - 3 (4,05\%) випадків. При виявленні інорільтрату усім хворим проводили терапію, що включала в себе антибактеріальні засоби і була адаптована до мікрофрлори, яку висівали 3 виділень із дренажів, нестероїдні протизапальні засоби, локально - компреси та фрізіотерапію. При нагноєнні виконували активне хірургічне дренування, що в більшості

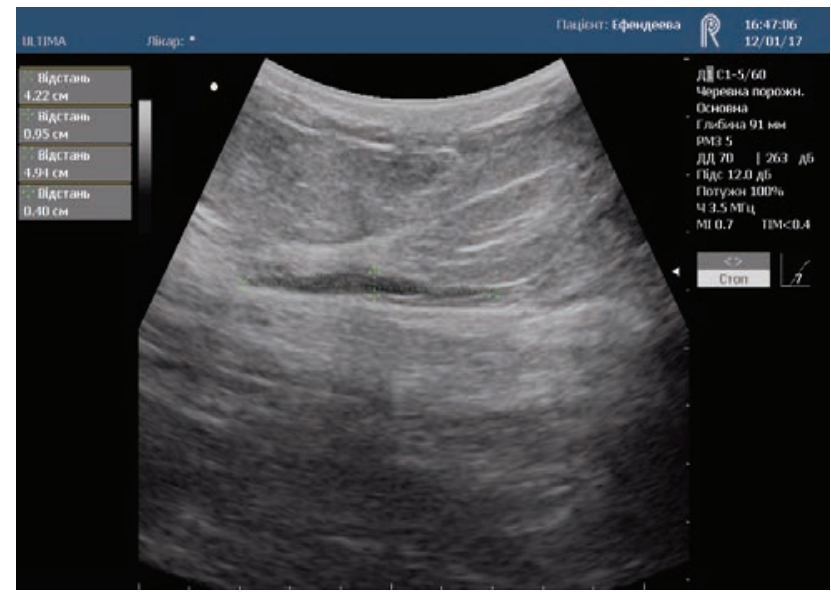

Рис. 2. Серома після алогерніопластики за типом "onlay" за даними сонографії в пацієнта основної групи. випадків не потребувало експлантації сітки. У 4 пацієнтів з групи порівняння було виконано експлантацію ППС після попередньо виконаної методики "onlay" (рис. 3).

Часто операційне втручання на тлі анестезіологічного знеболювання супроводжується рівнем артеріального тиску в межах 110-90/80-70 мм рт. ст., при яких кровоточивість тканин значно менша, що не вимагає підвищеної уваги хірурга до проведення ретельного гемостазу. В ранньому післяопераційному періоді на тлі збільшення артеріального тиску та призначення антикоагулятної терапії створюються умови до відновлення кровоточивості та утворення гематом. Додатковими предикторами їх виникнення вважаємо "спадання" лігатур та непостійність коагуляційного гемостазу. Тому гематому, як раннє ускладнення, в групі порівняння виявили у 67 (11,22 \%) осіб та 35 (4,26 \%) пацієнтів основної групи. В групі порівняння після виконання методик за типом "onlay" - 26 $(38,81 \%)$, за типом "inlay" - 22 (32,83 \%), за типом "sublay" - 17 (25,37\%), ВТГП - 2 (2,98\%).

Діагноз в більшості випадків встановлювали клінічно (гіпотензія, пітливість, тахікардія, зниження показників червоної крові) за відсутності ознак зовнішньої кровотечі. У таких випадках з метою виявлення гематоми необхідно виконати сонограсрічне дослідження чи комп'ютерну томографрію (КТ) (рис. 4), після яких можуть діагностувати гіперденсивну рідину, більш-менш однорідну за характером, що не підсилюється після введення контрасту. При тривалій кровотечі на КТ вияляють зображення контрастної екстравазації. У цій ситуації існує два способи її зупинки: відкрите хірургічне втручання; селективна емболізація.

В основній групі переважно через збільшення об'єму та травматичності операційного втручання, що включає анатомічне роз'єднання тканин передньої черевної стінки, гематоми частіше виникали після виконаної методики за типом "CST" у 21 (60,0 \%) пацієнта, разом 3 тим, як після "onlay" - в 12 (34,28 \%), ВТГП - у 2 (5,71 \%) хворих. Гематоми в більшості випадків були нерозповсюдженими, невеликих розмірів, не нагноювалися та не потребували хірургічної корекції.

Тривалу лімфорею, як ускладнення, спостерігали при імплантаційних методах герніопластики, особливо при застосуванні "важких" ППС за методикою "onlay". При мобілізації шкірно-жирового клаптя в більшості випадків

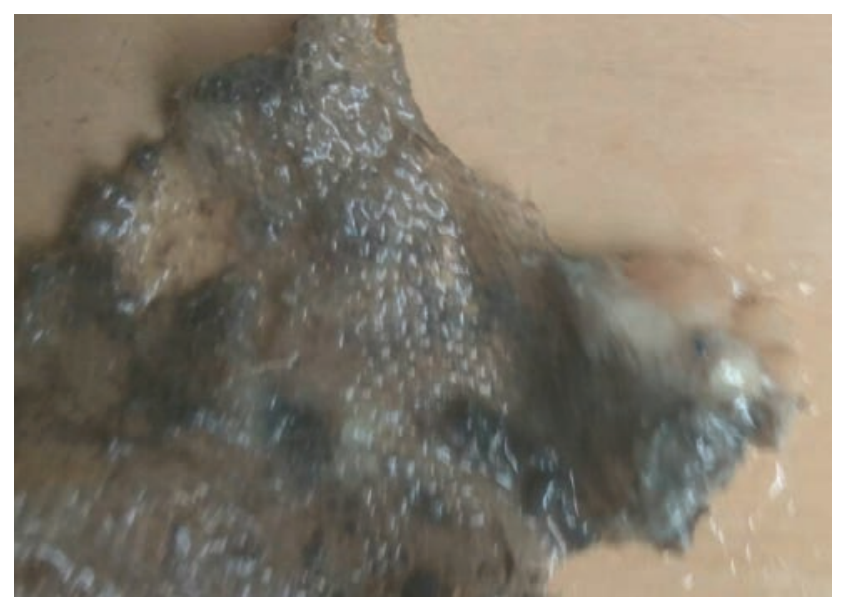

Рис. 3. Видалений фррагмент поліпропіленової сітки після нагноєння та відторгнення. 


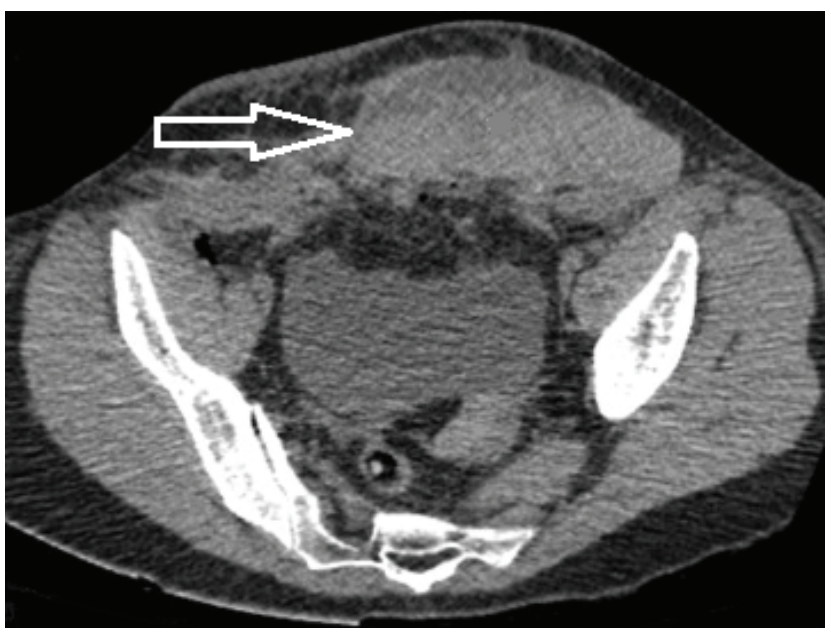

Рис. 4. Гематома передньої черевної стінки після алогерніопластики за типом "sublay".

пересікають судини та лімфатичні колектори, що живлять підшкірно-жирову клітковину, створюючи умови для порушення лімфатичного відтоку та надмірної ексудації. Наявність чужорідного тіла, тобто ППС, такожє різновидом асептичного запалення з пролонгацією фрази ексудації. Тому в групі порівняння таке ускладнення ми діагностували у 44 (7,37 \%) осіб, а в основній групі тільки у 21 (2,55\%) пацієнта. Така суттєва різниця зумовлена значною кількістю операцій за типом "onlay", виконаних у цей період (2001-2009рр.), разом з тим, як після 2010 р. переважали менш травматичні хірургічні втручання - "sublay".

Інфрікування післяопераційної рани з подальшим нагноєнням було у 21 (3,51 \%) пацієнта групи порівняння та в 13 (1,58 \%) осіб основної групи. Найчастіше воно ускладнювалося унаслідок нелікованої вчасно сероми та/ чи гематоми на тлі низької зниженої імунорезистетності відносно умовно-патогенної фрлори, великими площами ранової поверхні, тривалістю операційного втручання, при використанні "важких" ППС за методиками "onlay", зрідка "sublay".

За клінічними ознаками абсцедування, хворих сонографрічно обстежували, де виявляли наявність скупчення рідини неоднорідної ехоструктури, інколи з наявністю пухирців газу (рис. 5).

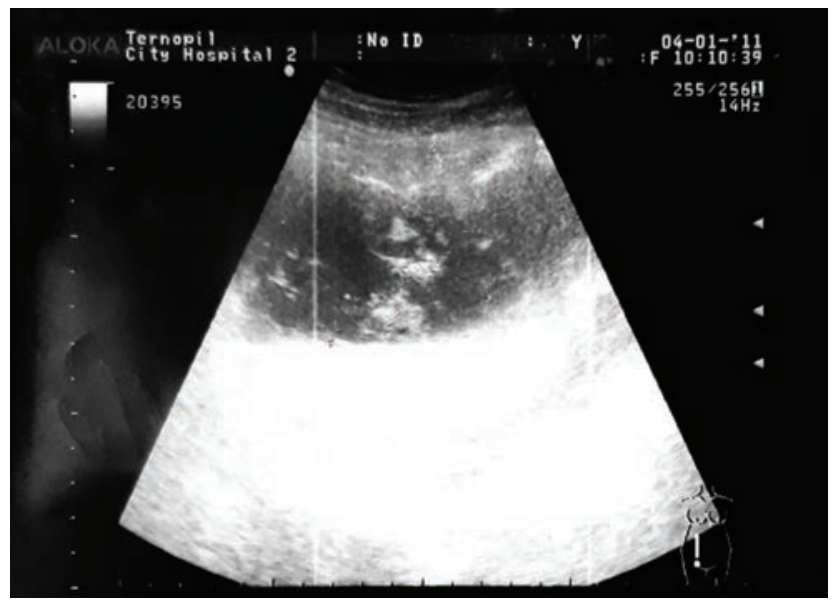

Рис. 5. Сонограсрічна картина абсцесу передньої черевної стінки за умови виконання алогерніопластики за типом "onlay".
У рідкісних випадках при ретромускуляному розміщенні ППС сонографічна діагностика була малоінфрормативною, тому обстеження доповнювали виконанням КТ.

У половини оперованих із групи порівняння дане ускладнення розвинулося після виконання методик "onlay" - 12 (57,14\%), а в основній групі - після "CST"методу - 7 (53,84 \%). Адекватно розкривали та дренували гнійник з обов'язковим бактеріальним посівом вмісту, використовували розчини антисептиків для промивання, активну аспірацію, доповнювали антибактеріальною, протизапальною терапією. Очищені рани зі свіжою грануляційною тканиною закривали вторинними швами.

Ще одним різновидом раннього місцевого ускладнення $€$ крайовий некроз шкіри післяопераційної ран, що виник у 12 (2,01 \%) пацієнтів групи порівняння та в 29 (3,52 \%) осіб основної групи відповідно. Крайовим некрозом вважали лише ті клінічні ситуації, які потребували додаткової хірургічної корекції у післяопераційний період. Причинами його виникнення було значне порушення кровопостачання шкіри та підшкірно-жирової клітковини, особливо при виконанні герніопластик, доповнених дерматоліпектомією, з приводу надмірного натягу тканин, особливо в центральній частині, а також у хворих із абдомінальним компартмент-синдромом чи парезом кишечника, що призводить до вираженої ішемізації тканин передньої черевної стінки, тим більше на тлі носіння бандажного пояса (рис. 6).

Застосовували раннє зняття швів, некректомію, антигіпоксичну терапію, мазеві пов'язки 3 накладанням вторинно відстрочених швів. Перспективним на сьогодні вважаємо застосування в цих випадках VAC-терапії, яка сприяє виведенню надмірного ексудату тим самим, пришвидшуючи утворення грануляційної тканини.

Загальні ускладнення серед 1419 пацієнтів обох груп діагностовано у 76 (5,35 \%) осіб. В групі порівняння їх було 53 (8,87 \%) випадків, в основній групі - 23 (2,79\%).

Тромбоемболія легеневої артерії (ТЕЛА) у ранньому післяопераційному періоді розвивається переважно у пацієнтів із групи ризику, що включає: вік старше 40 років, наявне ожиріння, варикозна хвороба підшкірних вен нижніх кінцівок із порушенням клапанного апарату вен гомілок, серецево-легенева недостатність.

Попри стандартно проведену антикоагулянтну терапію та згідно з визначеним ризиком тромбоемболічних

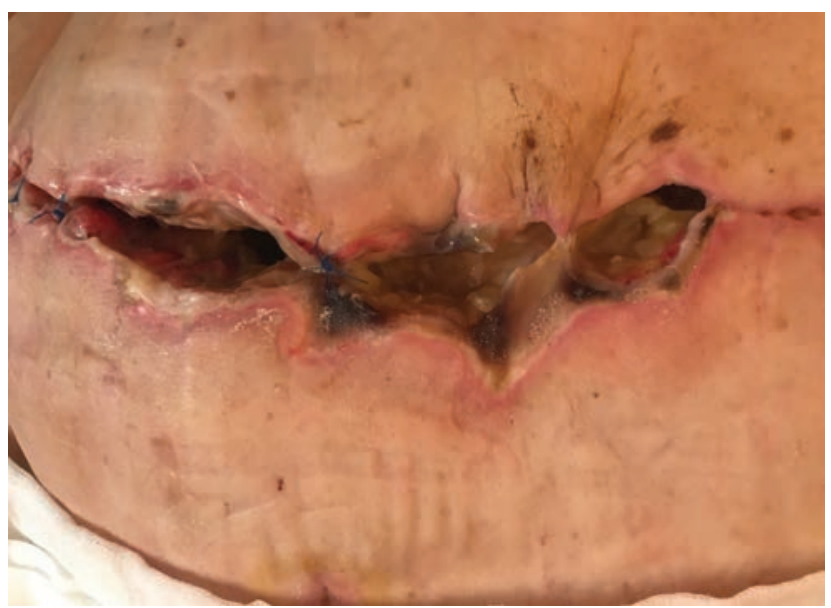

Рис. 6. Крайовий некроз шкіри післяопераційної рани після алогерніопластики за типом "onlay". 
ускладнень за шкалою за J. Caprini в 9 (1,51 \%) осіб групи порівняння та у 4 (0,49%) пацієнтів основної групи розвинулося дане ускладнення. Усі пацієнти з групи порівняння, в яких виникла тромбоемболія, померли.

Серед пацієнтів основної групи 3 оперованим особам вдалося на тлі активного тромболізису, гепаринотерапії (1000 ОД/год) та постановки кава-срільтру ліквідувати явища ТЕЛА. Один пацієнт, незважаючи на проведені терапевтичні зусилля, помер від масивної ТЕЛА.

Абдомінальний компартмент-синдром належить до серйозних ускладнень раннього післяопераційного періоду в пацієнтів, яких прооперували з приводу великих та гігантських ПВГ та ПОВГ.

Причинами для розвитку такого стану є значне підвищення внутрішньочеревного тиску (ВЧТ) за рахунок переміщення внутрішніх органів з грижевого мішка в черевну порожнину в пацієнтів із великими та гігантськими грижами, проведення натяжної герніопластики без урахування змін показників ВчТ, так як більшість хірургів, незважаючи на певні технічні складнощі, старається відновити анатомічну архітектуру передньої черевної стінки 3 подальшим укріпленням лінії швів апоневрозу ППС, виконуючи тим самим натяжну алогерніопластику. Зважаючи на те, що в більшості випадків пацієнтами є люди похилого та старечого віку з вираженою коморбідністю, ризик виникнення абдомінальний компартмент-синдром (АКС) значно зростає.

Підвищений внутрішньочеревний тиск (ВЧТ) створює значну компресію на ділянку нижньої порожнистої вени, тим самим зменшуючи на 15-20 \% венозний кровобіг по ній. Наявність супутніх порушень метаболізму, дихання, гемодинаміки, сечовиділення, парез кишечника, а також гіповолемія пришвидшують розвиток АКС.

Так, АКС у групі порівняння розвинувся у 12 (2,01\%) осіб, в основній групі -у 5 (0,61 \%) пацієнтів. 3'ясовуючи, після яких типів операційних втручань розвинулося дане ускладнення, встановлено, що в групі порівняння у 5 (41,67\%) осіб після ВТГП і в 7 (58,33 \%) - після "onlay" методик.

В основній групі АКС розвинувся після ВТГП в 1 (20,0\%), після "onlay" - у 2 (40,0 \%) та після "sublay" - у 2 (40,0 \%). В обох дослідних групах рівень АКС не перевищував I-II ступенів (15-16 мм рт. ст.).

Корекцію даного ускладнення проводили згідно з його проявами: антигіпоксична терапія, антикоагулянтна терапія, пролонгована інтубація трахеї зі штучною вентиляцією легень, у певних випадках у СРАР-режимі, спазмолітична терапія. Надавали пацієнту напівсидячого положення в ліжку із зігнутими в колінах ногами. У всіх випадках було досягнуто позитивної динаміки регресу клінічних проявів АКС, а тому хірургічної декомпресії 3 метою зняття внутрішньочеревної напруги не проводили.

Пневмонія, як післяопераційне ускладнення після лікування ПВГ і ПОВГ, виникла у 20 (3,35 \%) обстежуваних пацієнтів групи порівняння та у $8(0,97 \%)$ основної групи й носила застійний характер. У більшості випадків $(70,0 \%)$ вона розвивалася як наслідок перенесеного АКС.

Просрілактика респіраторного дистрес-синдрому (iнтраопераційно та в післяопераційний період внутрішньовенно вводили амброксол у дозі 2,0 три рази на день), антибіотиктеріальна терапія, адекватна штучна вентиляція легень під час та після операції, ретельна санація дихальних шляхів, післяопераційна дихальна гімнастика, рання активізація сприяли зменшенню частоти виникнення даного ускладнення.
Такі ускладнення, як гострий інфраркт міокарда та гостре порушення мозкового кровообігу (ГПМК), найчастіше виникали в пацієнтів з індексом коморбідності 4-6 на тлі вираженої супутньої серецево-судинної патології. У віковому аспекті важливим чинником їх розвитку слугував стрес, спричинений проведенням операційного втручання. Гострий інсраркт міокарда в групі порівняння діагностовано в 7 (1,17\%) осіб, а в основній групі - у 4 (0,48 \%), ГПМК - у $5(0,84 \%)$ та у $2(0,24 \%)$ пацієнтів відповідно.

Серед пізніх місцевих ускладнень найчастіше спостерігали лігатурні нориці, особливо в період 20012009 рр. - 27 (4,52 \%) хворих. В основній групі дане ускладнення виявлено у $3(0,36 \%)$ пацієнтів. Таку різницю пояснюють тим, що досить широко застосовують полісріламентний шовний матеріал (шовк, капрон) у період 2001-2009 рр. для сріксації ППС до апоневрозу, який за своєю структурою більше схильний до контамінації патогенною мікрофлорою, що призводить у подальшому до нагноєння післяопераційної рани 3 фрормуванням лігатурних нориць чи ізольованого їх виникнення.

Натомість, у період з 2010 р. широко впроваджують у хірургічну практику монофріламентний шовний матеріал, стійкий до інфрікування. При виконанні усіх типів герніопластик таке ускладнення практично не зустрічається. Клінічно, лігатурні нориці проявлялися наявністю тривалих ран із серозно-гнійними виділеннями, що не заживають (рис. 7), які не піддавалися консервативним методам лікування та потребували активної хірургічної корекції, що включала висічення лігатурного абсцесу разом із лігатурою у межах здорових тканин.

Хронічний біль був у 22 (3,68 \%) пацієнтів 3 групи порівняння. Хронічним післяопераційним болем ми вважали біль, тривалість якого перевищувала 3-6 місяців після проведеного операційного втручання. В цій групі він був у 21 (95,45 \%) осіби після ВТГП. Основними причинами його виникнення вважали пересічення нервів, термічну ї травму, стиснення в шві при фріксації ППС, близький контакт із сітчастим імплантом, у більшості випадків при застосуванні "важких" ППС та вростання нервів у сполучнотканинну капсулу, що утворюється навколо сітки. Окрім цього, фріксація ППС П-подібними швами через товщу м'язово-апоневротичного шару передньої черевної стінки супроводжується значною ішемізацією її структур, що також патогенетично обґрунтовує появу хронічного болю в післяопераційний період.

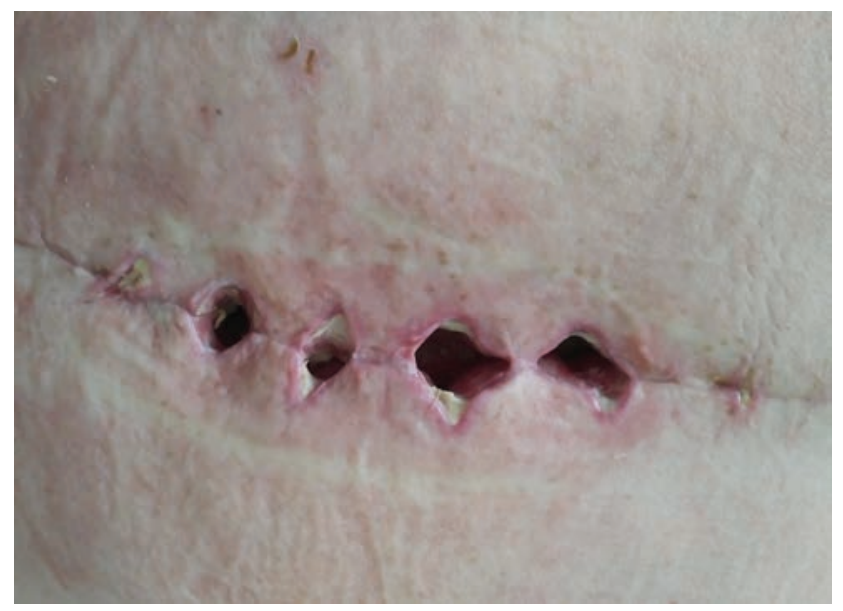

Рис. 7. Лігатурні нориці після алогерніопластики за типом "onlay". 
В основній групі хронічний біль виявлено в 5 (0,61 \%) оперованих пацієнтів. Лікування його проводили лише консервативним методом (нестероїдні протизапальні препарати, фрізіотерапія, новокаїнові блокади). В жодному випадку не було виконано додаткового хірургічного втручання.

Наступним ускладненням за частотою виявлення було відторгнення ППС (рис. 8). У період 2001-2009 рр. діагностовано $15(2,51 \%)$ випадків, в основній групі - 5 (0,61 \%). Найчастіше відторгнення ППС спостерігали при методиці "onlay". у 10 пацієнтів із даним ускладненням було діагностовано супутній цукровий діабет 2 типу та синдром недиференційованої дисплазії сполучної тканини (НДСТ). В інших випадках відторгнення ППС виникло після сероми, яку довго не ліквідували, що часто призводило до нагноєння.

Під час клінічного обстеження мешому виявили у 10 $(1,67 \%)$ осіб із групи порівняння та в $7(0,85 \%)-3$ основної групи. Причиною виникнення мешом вважаємо наявність утворення ізольованої кісти при тривалій серомі навколо сітчастого імплантата, без клінічних проявів у ранньому післяопераційному періоді. Пацієнтів із даним ускладненням виявляли переважно під час проходження планового сонографічного обстеження через 3-6 місяців. Лікували мешому лише хірургічним шляхом - видаляли її із капсулою (рис. 9) над ППС, інколи з фррагментами імплантата. Експлантації сітки не проводили у зв'язку з доброю інтеграцією її у тканини передньої черевної стінки.

Міграцію сітки виявлено у 9 (1,0 \%) та 5 (0,61 \%) осіб групи порівняння та основної групи відповідно. Причинами їх, як і при відторгненні, були синдром НДСТ та цукровий діабет. Окрім них, технічні погрішності при фріксації

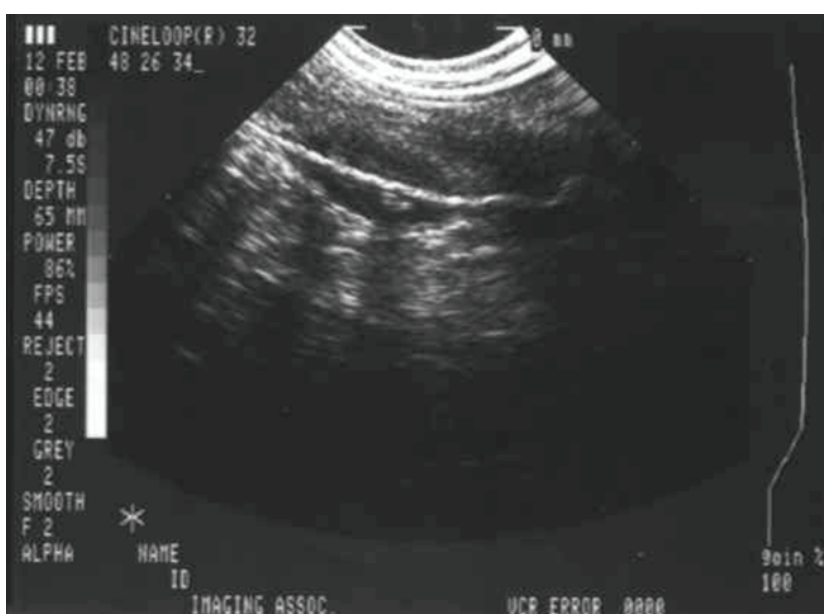

Рис. 8. Крайове відторгнення поліпропіленової сітки після виконання методики "onlay".
ППС (рідкі шви, розв'язування їх, мала товщина поліпропіленової нитки, тривалий парез кишечника, надсадний кашель у післяопераційному періоді).

Утворення кишкових нориць діагностовано у 8 (0,56 \%) осіб, що часто проявлялося 5 (62,5\%) виділенням кишкового вмісту 3 нориці передньої черевної стінки, у 2 (25,0 \%) випадках явищами перитоніту, в 1 (12,5 \%) - обтураційною кишковою непрохідністю унаслідок пролежня та міграції ППС у кишечник. В усіх цих випадках виконували повторні операційні втручання.

За даними нашого дослідження, у 250 (17,62 \%) пацієнтів після різних типів операційних втручань розвинувся рецидив грижі. Поділ рецидиву за типами виконаних операцій у різні періоди дослідження подано в таблиці.

Як видно з таблиці, найбільшу частоту рецидиву спостерігали в пацієнтів після виконання власне тканинної герніопластики, що становило 36,07 \% від усіх оперованих пацієнтів за даною методикою. На другому місці за частотою рецидиву були хворі після виконаної алогерніопластики за типом "inlay" - 19,63 \%. Частота рецидиву після алогерніопластики за типом "onlay" становить 10,58 \%. Після виконання методики "sublay" отримані показники значно відрізняються невисоким відсотком рецидивів порівняно з іншими способами герніопластики. Так, відсоток рецидиву склав тільки 6,01 \%. Єдиним методом операційного лікування ПОВГ, при якому ми не відмітили рецидиву, був спосіб герніопластики з анатомічним розподіленням компонентів передньої черевної стінки, яке виконували в двох варіантах - без використання ППС за Ramirez та комбінований із використанням ППС.

Можливо такі дані пояснюються невеликою кількістю виконаних даних операційних втручань 45 (3,17 \%) та короткими термінами спостереження (4 роки).

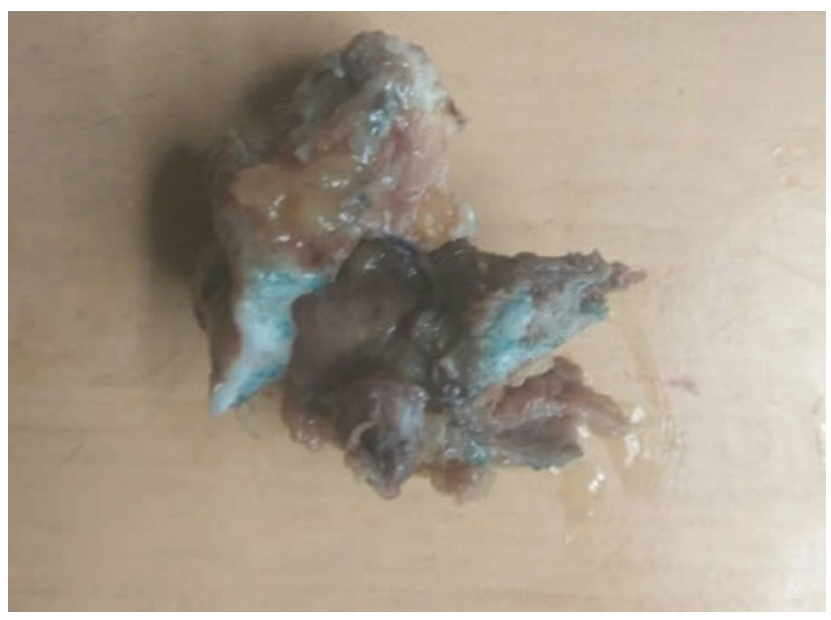

Рис. 9. Видалений препарат мешоми з елементами "важкої" поліпропіленової сітки.

Таблиця. Частота рецидиву після різних типів герніопластик в усіх оперованих пацієнтів

\begin{tabular}{|c|c|c|}
\hline Тип виконаних герніопластик & Загалом операцій & Частота рецидиву \\
\hline ВТГП & 438 & $158(36,07 \%)$ \\
\hline За типом "onlay" & 463 & $49(10,58 \%)$ \\
\hline За типом "inlay" & 107 & $21(19,63 \%)$ \\
\hline За типом "sublay" & 366 & $22(6,01 \%)$ \\
\hline За методикою "CST" & 45 & - \\
\hline Усього & 1419 & $250(17,62 \%)$ \\
\hline
\end{tabular}


Висновки 1. Значна частка операційних втручань із приводу ПВГ та ПОВГ супроводжується виникненням післяопераційних ускладнень. Місцеві ранні післяопераційні ускладнення спостерігали у 522 (36,78 \%) осіб, а загальні - в 76 (5,36 \%) пацієнтів. У групі порівняння місцеві ускладнення мали місце в 311 (52,09 \%) хворих, а в основній групі - у 211 (25,67 \%) осіб. Така ж тенденція була при поділі загальних ускладнень: 53 (8,88 \%) та 23
(2,79 \%) відповідно, що пояснюється більш недосконалими методами способів хірургічних втручань та широким застосуванням "важких" поліпропіленових сіток.

2. Завдяки впровадженню сучасних та удосконаленню існуючих способів хірургічного лікування хворих на первинні та післяопераційні вентральні грижі, кількість ранніх місцевих та загальних, а також пізніх ускладнень, вдалося зменшити майже у 2 рази.

\section{СПИСОК ЛІТЕРАТУРИ}

1. Борисов А. Э. Применение полипропиленовой сетки при больших и гигантских грыжах передней черевной стенки / А. Э. Борисов, С. К. Малкова, В. В. Тоидзе // Весник хирургии. 2012. - Т. 161, № 6. - С. 76-78.

2. Дзюбановський І. Я. Місцеві мікрози в хірургії післяопераційних вентральних гриж / І. Я. Дзюбановський, В. І. П'ятночка, К. Г. Поляцко // Шпитальна хірургія. - 2009. - № 4. - С. 19-22.

3. Кузнецов Н. А. Роль операционного доступа в развитии послеоперационных вентральных грыж / Н. А. Кузнецов, И. В. Счастливцев, С. Н. Цаплин // Хирургия. - 2011. - № 7. C. $62-66$.

4. Оптимізація вибору способу алопластики при післяопераційних грижах живота гігантського розміру / Я. П. Фелештинський, В. Ф. Ватаманюк, С. А. Свиридовський [та ін.] // Галицький лікарський вісник. - 2012. - Т. 19, № 3 (ч. 2). - С. 114-116.

5. Оптимізація просрілактики ранових ускладнень після алогерніопластики післяопераційних гриж черевної стінки / Я. П. Фелештинський, В. Ф. Ватаманюк, В. В. Преподобний, В. В. Сміщук // Клінічна хірургія. - 2012. - № 10 (836) (додаток). - C. 57.

6. Systematic review and meta-regression of factors affecting midline incisional hernia rates: analysis of 14,618 patients / D. C. Bosanquet, J. Ansell, T. Abdelrahman [et al.] // PLoS One. 2015. - Vol. 10. e0138745

7. Outcomes of synthetic mesh in contaminated ventral hernia repairs / A. M. Carbonell, C. N. Criss, W. S. Cobb [et al.] // J. Am. Coll. Surg. - 2013. - Vol. 217. - P. 991-998.
8. Randomized clinical trial comparing lightweight composite mesh with polyester or polypropylene mesh for incisional hernia repair / J. Conze, A. N. Kingsnorth, J. B. Flament [et al.] // Br. J. Surg. -2005. - Vol. 92. - P. 1488-1493.

9. Nationwide prospective study of outcomes after elective incisional hernia repair / F. Helgstrand, J. Rosenberg, H. Kehlet [et al.] // J. Am. Coll. Surg. - 2013. - Vol. 216. - P. 217-228.

10. Modified hernia grading scale to stratify surgical site occurrence after open ventral hernia repairs / A. E. Kanters, D. M. Krpata, J. A. Blatnik [et al.] // J. Am. Coll. Surg. - 2012. Vol. 215. - P. 787-793.

11. Comparison of outcomes of synthetic mesh vs suture repair of elective primary ventral herniorrhaphy: a systematic review and meta-analysis / M. T. Nguyen, R. L. Berger, S. C. Hicks [et al.] // JAMA Surg. - 2014. - Vol. 149. - P. 415-421

12. Central failures of lightweight monofilament polyester mesh causing hernia recurrence: a cautionary note / C. C. Petro, E. H. Nahabet, C. N. Criss [et al.]// Hernia. -2015. - Vol. 19. - P. 155-159.

13. Epidemiology and cost of ventral hernia repair: making the case for hernia research / B. K. Poulose, J. Shelton, S. Phillips [et al.] // Hernia. -2012. - Vol. 16. - P. 179-183.

14. Financial implications of ventral hernia repair: a hospital cost analysis / D. Reynolds, D. L. Davenport, R. L. Korosec [et al.] // J. Gastrointest. Surg. -2013 .

15. Evaluation of surgical outcomes of retro-rectus versus intraperitoneal reinforcement with bio-prosthetic mesh in the repair of contaminated ventral hernias / M. J. Rosen, G. Denoto, K. M. Itani [et al.] // Hernia. - 2013. - Vol. 17. - P. 31-35.

Отримано 05.11.18 Електронна адреса для листування: vladymyrpiatnochka@gmail.com

\section{ANALYSIS OF LOCAL AND GENERAL COMPLICATIONS IN THE TREATMENT OF PRIMARY AND POSTOPERATIVE VENTRAL HERNIAS FOR THE PERIOD OF 2001-2017}

Summary. The introduction of modern methods and alloplastic materials into surgical practice has significantly improved the results of surgical treatment of patients with ventral and postoperative ventral hernia. However, the implantation of synthetic material in the tissue of the anterior abdominal wall is not without drawbacks in their application, as it is accompanied by different local tissue response, especially when implanting "heavy" networks, which leads to the development of complications, the frequency of which is from 7.9 to $49.2 \%$. Analysis of the results determines the relevance of this study.

The aim of the study - to analyze the main causes of local and general complications in the treatment of patients with primary and postoperative ventral hernias.

Materials and Methods. There were formed two periods of the study of the number of the 1419 operated: from 2001 to 2009,597 (42.07\%) patients - comparison group and from 2010 to 2017; 822 (57.93\%) patients - main group. Among the patients of the comparison group $286(47.91) \%$ persons were with primary ventral hernia, and $344(41.85 \%)$ patients - in the main group with primary hernia. There were 311 (52.09\%) people in the control group, and 478 (58.15\%) in the main group.

Results and Discussion. Of all 1.419 operated patients, local early postoperative complications were diagnosed in $522(36.78 \%)$ patients. Common early complications were found in 76 (5.36 \%) patients. In the comparison group, local complications occurred in $311(52.09 \%)$ patients, and in the main group in $211(25.67 \%)$ patients. The same trend was observed in the distribution of common complications: $53(8.88 \%)$ and $23(2.79 \%)$, respectively. We observed seroma in $124(23.75 \%)$, infiltrates - in $156(28.88 \%)$, 
hematoma - in 102 (19.54\%), suppuration - in 34 (6.51\%), prolonged lymphorrhea - in 65 (12.45\%) patients. Common complications among 1419 patients of both groups were diagnosed in 76 (5.35\%) persons. In the comparison group there were $53(8.87 \%)$ cases, in the main group - $23(2.79 \%)$. Among late local complications, ligature fistulas were most often observed, especially in the period of 2001-2009-27 (4.52\%). In the main group, this complication was detected only in $3(0.36 \%)$ patients. PPS rejection was diagnosed in $15(2.51 \%)$ cases. During the clinical study, a mesh appeared in $10(1.67 \%)$ of the comparison group and in $7(0.85 \%)-$ in the main group; mesh migration was detected in $9(1.0 \%)$ and $5(0.61 \%)$ persons of the comparison group and the main group. In 250 (17.62 \%) patients, after various types of surgical interventions, a hernia recurred.

Conclusion. The introduction of modern and improvement of existing methods of surgical treatment of patients with primary and postoperative ventral hernias, reduced the number of early local and general as well as late complications by almost 2 times.

Key words: ventral hernia; postoperative ventral hernia; alohernioplasty; complications.

(В. И. Пятночка, И. Я. Дзюбановский, А. М. Продан

ГВУз “Тернопольский государственный медицинский университет имени И. Я. Горбачевского”

\section{АНАЛИЗ МЕСТНЫХ И ОБЩИХ ОСЛОЖНЕНИЙ ПРИ ЛЕЧЕНИИ ПЕРВИЧНЫХ И ПОСЛЕОПЕРАЦИОННЫХ ВЕНТРАЛЬНЫХ} ГРЫЖ ЗА ПЕРИОД 2001-2017 ГГ.

Резюме. Внедрение в хирургическую практику современных методов и аллопластических материалов значительно улучшило результаты хирургического лечения больных вентральной и послеоперационной вентральной грыжей. Однако имплантация синтетического материала в ткани передней брюшной стенки не лишена недостатков в их применении, так как сопровождается разной местной реакцией тканей, особенно при имплантации "тяжелых" сеток, что приводит к развитию осложнений, частота которых составляет от 7,9 до 49,2 \%. Анализ полученных результатов обусловливает актуальность данного исследования.

Цель исследования - провести анализ основных причин возникновения местных и общих осложнений при лечении больных первичными и послеоперационными вентральными грыжами.

Материалы и методы. Сформировано два периода исследования из числа 1419 оперированных: с 2001 г. по 2009 г. 597 $(42,07 \%)$ пациентов - группа сравнения, и с 2010 г. по 2017 г. 822 (57,93 \%) человека - основная группа. В группе сравнения лиц с первичной вентральной грыжей было 286 (47,91 \%), а в основной группе с первичными грыжами - 344 (41,85 \%); с послеоперационными в группе сравнения - 311 (52,09 \%) человек, а в основной группе - 478 (58,15 \%).

Результаты исследований и их обсуждение. Из всех 1419 оперированных пациентов местные ранние послеоперационные осложнения диагностированы у 522 (36,78 \%) человек. Общие ранние осложнения мы установили у 76 (5,36 \%) пациентов. В группе сравнения местные осложнения имели место у 311 (52,09 \%) больных, а в основной группе - у $211(25,67 \%)$ человек. Такая же тенденция наблюдалась в распределении общих осложнений: 53 (8,88 \%) и 23 (2,79 \%) соответственно. Серому мы наблюдали у 124 (23,75 \%), инфильтраты - у 156 (28,88 \%), гематому - у 102 (19,54 \%), нагноение - у 34 (6,51 \%), длительную лимфорею - у 65 (12,45 \%) пациентов. Общие осложнения среди 1419 больных обеих групп диагностировано у 76 (5,35\%) человек. В группе сравнения их было 53 (8,87\%) случаев, в основной группе - 23 (2,79\%). Среди поздних местных осложнений чаще всего наблюдали лигатурные свищи, особенно в период 2001-2009 гг. - 27 (4,52 \%). В основной группе данное осложнение выявлено лишь у 3 (0,36 \%) пациентов. Отторжение полипропиленовой сетки (ППС) было у 15 (2,51 \%) случаев. Во время клинического исследования мешома возникла у $10(1,67 \%)$ лиц группы сравнения и у $7(0,85 \%)-$ основной группы, миграцию сетки выявлено у 9 (1,0 \%) и 5 (0,61 \%) человек группы сравнения и основной группы. У 250 (17,62 \%) пациентов после различных типов операционных вмешательств развился рецидив грыжи.

Выводы. Внедрение современных и усовершенствование существующих способов хирургического лечения больных первичными и послеоперационными вентральными грыжами сократило количество ранних местных и общих, а также поздних осложнений почти в 2 раза.

Ключевые слова: вентральная грижа; послеоперационная вентральная грыжа; аллогерниопластика; осложнения. 